\title{
'N NEURO-EVOLUSIONÊRE EN NEUROFISIOLOGIESE BENADERING TOT DIE ONDERSOEK EN BEHANDELING VAN VERWORWE DIS- ARTRIE
}

\author{
ANITA VAN DER MERWE M.A.LOG. (PRETORIA) \\ Departement Sproakheelkunde, Universiteit van Pretoria
}

\section{OPSOMMING}

Die konvensionele benadering to t verworwe disartric soos dit gevind word in die literatuur word kortliks bespreek. Die noodsaaklikheid vir 'n gewysigde benadering wat praktiese leidrade aan die spraak terapcut sal verskaf, word bcklemtoon. Dic opkoms van die neuroevolusionêr-gefundeerde benadering tot screbrale verlamming, met ander woordc, tot kongenitale disartrie, word genoem. Sover bekend, is daar geen georganiscerde gegewens in die literatuur wat die neuro-evolusie van spraakmotoriek blootlê vanaf die mees outomatiese, mees gcorganiseerde en mees ecnvoudige vlak tot die meer willekeurige, meer komplckse, en minder georganiseerde vlak van funksionering nie. Bckende gegewens in verband met spraak is hipoteties georden en 'n hiërargiese spraakskema is opgestel wat die neuro-cvolusie van spraak blootlê. Op grond van dic skema en met inagneming van neuro-fisiologiese disfunksies, is 'n ondersoek program opgestel wat die spraakprobleem van die verworwe disartriegeval in sy geheel ondersoek. Bchandeling geskied aan die hand van die riglyne wat die skema aandui. Deur die gebruik van tocpaslike spraakterapeutiese metodes word bcoog om 'n herevolusie te bewerkstellig waar moontlik.

\section{SUMMARY}

The conventional approach to acquired dysarthria as found in the literature, is briefly discussed. The necessity for an altered approach, which will provide practical guidelines for speech therapists, is emphasized. The approach to cercbral palsy (in other words to congenital dysarthria) based on neuro-evolutional theory, is mentioned. As far as is known, there are no organised data in the literature that describe the ncuro-evolution of speech motor-co-ordination from the most automatic, most organized and simplest level to the more voluntary, more complex and less organized level of functioning. Known data concerning speech have been hypothetically ordered and a hierarchical speech scheme describing the neuro-evolution of speech was constructed. Based on this scheme and taking the neurophysiological dysfunction into account, an examination procedure which examines acquired dysarthria as a whole, has been compiled. Therapy follows the guidelines indicated by the scheme.

Disartrie is 'n Griekse woord wat letterlik beteken 'n versteuring van artikulasie as gevolg van 'n' letsel van die perifere of sentrale senuweestelsel. ${ }^{18} \mathrm{Die}$ term behels egter meer as dit en verwys na defektiewe motoriese beheer van die totale spraakmeganisme uitgesonderd die simboliese. Dit verwys na spraakprobleme as gevolg van paralise, swakheid, of swak koördinasie van spraakspiere en dit sluit in artikulasie, fonasie, respirasie en resonansie. ${ }^{5,10}$ Die term "verworwe" dui aan dat die toestand nie aangebore is nie, maar dat gestabiliseerde spraak reeds bestaan het voor die toestand ingetree het. 
Aanduidings van belangstelling in verworwe disartrie word in die literatuur gevind vanaf die begin van hierdie eeu. Navorsing op dié gebied volg veral twee benaderingswyses. Enersyds word een of meer van die spraaksimptome wat kenmerkend is van verworwe disartrie, ondersoek. Enkele simptome soos byvoorbeeld hipernasaliteit, ${ }^{19}$ verstaanbaarheid, ${ }^{15}$ wanartikulasie, disdiadokokinese,${ }^{14}$ en verminder de beweeglikheid van artikulators, ${ }^{7}$ word in isolasie bestudeer. Die verband met ander simptome en die onderliggende neuro-fisiologiese disfunksie word dus nie duidelik toegelig nie.

Andersyds is die simptome wat in 'n spesifieke toestand voorkom, nagegaan. Baie aandag is geskenk aan Parkinsonisme, Veelvuldige Sklerose en Myasthenia Gravis. Verskeie nie-spesifieke terminologie is gebruik om die spraaksimptome te beskryf, byvoorbeeld "stadig", "geforseerd", "eksplosief" en "staccato". Beskrywing van 'n sekere toestand se simptome verskil van outeur tot outeur en die gevolg is 'n algemene verwarrende beeld.

Dieselfde neiging om die probleem oppervlakkig te benader, word gevind met betrekking tot die behandeling van verworwe disartrie. Metodes wat wissel vanaf die koumetode ${ }^{17}$ tot die gebruik van eksterne hulpmiddels byvoorbeeld 'n prostese vir nasale spraak, ${ }^{16}$ en chirurgiese kleefband, ${ }^{4}$ word beskryf. Elk van die metodes kan wel nuttig wees deurdat sekere simptome sodoende verlig word. Geen algemene beginsels word egter in die literatuur verskaf op grond waarvan al die simptome van alle gevalle van verworwe disartrie ondersoeir en behandel kan word nie.

Darley en sy medewerkers, ${ }^{5,6}$ doen in 1969 die mees omvattende studies tot op dat:ım. Spraaksimptome van al die verskillende tipes verworwe disartrie word bestudeer met as doel die samestelling van differensiaal-diagnostiese simptoomgroepe. Die simptome word verklaar en in verband gebring met die onderliggende neurofisiologiese disfunksie. Die praktiese implikasies van die studies is egter steeds beperk vir die spraakterapeut.

Gedurende die vyftigerjare is 'n groot deurbraak gemaak op die gebied van serebrale verlamming toe Bobath en Bobath neuro-evolusionêr georiënteerde terapiemetodes in fisioterapie begin toepas het. Mysak ${ }^{11}$ het die waarde van die benadering besef en dit ook toegepas op die behandeling van spraakprobleme van die serebraalverlamde kind. Mysak ${ }^{12}$ verklaar egter dat die enkele groot struikelblok in die weg van die praktiese toepassing van 'n neuro-evolusionêre benadering in spraakterapie, die gebrek aan georganiseerde materiaal op die gebied van oro-neuro-motoriese ryping van spraak, is. Kennis van dié gebied is noodsaaklik aangesien die motoriese probleme van die serebraalverlamde vanuit 'n neuro-evolusionêre oogpunt gesien word as 'n arrestásie of wanontwikkeling op die evolusieleer van motoriek. Die simptome van verworwe disartrie kan daarenteen gesien word as 'n devolusie van motoriek. Die herverskyning van infantiele orale reflekse by die volwasse brein-beseerde persoon soos beskryf deur, o.a. Brain, ${ }^{2}$ en Mysak, ${ }^{13}$ bevestig die aanname.

Ten einde die rasionaal van 'n neuro-evolusionêr-gefundeerde benadering te verstaan, is dit nodig om die konsep van evolusie en devolusie van die funksionering van die sentrale senuweestelsel en diè duplekse simptomatologie van neuropatologie kortliks te beskryf. Die welbekende neuroloog, John Hughlings Jackson, het in die vorige eeu hierdie beginsels gepostuleer, en dit bied steeds 
'n handige basis vir die bestudering van die simptome van neuropatologie.

$\mathrm{Jackson}^{9}$ onderskei 'n hiërargie in die sentrale senuweestelselareas en ook in die funksies van die areas. Onderskeid word hoofsaaklik gemaak tussen hoogste en laagste vlakke. Die funksies van die laagste vlak is minder kompleks of meer eenvoudig, meer georganiseerd en dus minder veranderbaar, en ook meer outomaties. Bewegings wat op dié vlak beheer word, toon min kompleksiteit en min spesialisasie. Dit is kenmerkend van gedrag net na geboorte. Die funksies van die hoogste vlak en gedrag wat beheer word op dié vlak, is minder georganiseerd, meer kompleks en meer willekeurig.

Mysak ${ }^{13}$ definieer die term "evolusie" as: " . . a an ascending development in a particular order'. Die genoemde onderskeid in funksies dui dus ook die orde van motoriese ontwikkeling aan. Ontwikkeling vind plaas vanaf die mees outomatiese funksies na die meer willekeurige, vanaf die mees eenvoudige na die meer komplekse en vanaf die mees georganiseerde, tot die funksies wat steeds verder georganiseer word. ${ }^{13}$ Daar is dus 'n ordelike verloop in motoriese ontwikkeling. Elke vlak van ontwikkeling is die resultat van die vorige vlak en die voorloper van die daaropvolgende vlak. ${ }^{3}$ Primitiewe motoriese response word geleidelik geïnhibeer namate hoër vlakke van ontwikkeling bereik word. ${ }^{1}$

Neuropatologie veroorsaak daarenteen 'n devolusie of afbraak van funksionering en gee aanleiding tot 'n duplekse simptomatologie volgens Jackson.' Negatiewe simptome is die verlies van funksies as gevolg van 'n letsel terwyl positiewe simptome die resultaat is van aktiwiteit of ooraktiwiteit van die intakte dele van die sentrale senuweestelsel wat vrygestel is van beheer deur hoër dele. 'n Voorbeeld van 'n negatiewe simptoom is 'n parese of paralise wat die gevolg is van 'n verlies van willekeurige beheer en 'n voorbeeld van 'n positiewe simptoom is die verskyning van infantiele reflekse. ${ }^{13}$

In terme van die leër van devolusie is die negatiewe element dus die verlies van die minder georganiseerde, meer komplekse en meer willekeurige funksies, terwyl die positiewe element die vrylating is van meer georganiseerde, meer eenvoudige en meer outomatiese funksies. Die verskynsel van duplekse simptomatologie bevestig dus die konsep van devolusie van motoriek as gevolg van neuropatologie.

Indien die neuro-evolusionêre beginsels van sentrale senuweestelselfunksies toegepas word op spraakmotoriek, impliseer dit 'n rangorde van kompleksiteit van spraakgedrag wat geleidelik tot stand kom en ook afgebreek kan word as gevolg van breinskade van die motoriese areas. Indien sodanige rangorde of evolusieleer saamgestel kan word, kan dit dus 'n raamwerk bied waarbinne verworwe disartrie ondersoek en behandel kan word. Die mate van devolusie kan nagegaan word en die heropbou van spraakfunksies kan geskied aan die hand van die riglyne wat die evolusieleer, of soos dit later genoem word, die hiërargiese skema, aandui.

Alvorens daartoe oorgegaan word om die neuro-evolusionêre beginsels toe te pas op spraak, moet genoem word dat die meer neurofisiologiese aspekte van verworwe disartrie nie geïgnoreer mag word nie aangesien dit van groot belang is in die behandeling. Motoriek en dus ook spraakmotoriek word beheer deur die gesamentlike werking van 'n aantal dele van die sentrale senuweestelsel. In 
die verskillende etiologiese groepe of ook genoem motoriese sindroomgroepe, word motoriek op 'n kenmerkende wyse aangetas. 'n Letsel van enige deel van die sentrale senuweestelsel wat motoriek beinvloed, sal waarskynlik 'n devolusie van spraakgedrag tot gevolg hê aangesien komplekse spraakfunksies afhanklik is van die gesamentlike werking van die verskillende dele van die sentrale senuweestelsel. Sover moontlik word die neurofisiologiese disfunksie, byvoorbeeld ' $n$ parese wat die uitvoer van meer of minder komplekse funksies verhoed, dus behandel ten einde 'n herevolusie te bewerkstellig. Waar beide die neuro-evolusionêre en neurofisiologiese komponente in ag geneem word, bied dit ' $n$ verantwoordbare rasionaal vir die on dersoek en behandeling van verworwe disartrie.

\section{DIE TOEPASSING VAN NEURO-EVOLUSIONERE BEGINSSELS OP SPRAAK}

Sover bekend bestaan daar geen georganiseerde gegewens wat die neuro-evolusie van spraak blootlê nie. In terme van die genoemde beginsels kan afgelei word dat ook spraakmotorick vanaf 'n mees outomatiese, mees georganiseerde en mees cenvoudige vlak na 'n meer willekeurige, minder georganiseerde en meer komplekse vlak van funksionering ontwikkel. Die infantiele orale reflekse kan gesien word as die laagste vlak van orale funksionering en as die beginpunt van vegetatiewe gedrag en spraakontwikkeling. Ingram ${ }^{8}$ sê dat die reflekse plaasvind via die medulla en op latere stadiums in willekeurige motoriese aktiwiteite gein tegreer word. Oor die verband wat daar bestaan tussen spesifieke orale reflekse en artikulasie-beweging kan slegs gespekuleer word.

Gestabiliseerde spraak is direk ge in isieerde en willekeurige bewegings, maar die presiese funksionering is afhanklik van die onderliggende onbewuste integrasic van die aktiwiteite van 'n komplekse reeks reflekse. Hierdie reflekssisteme verskaf die onbewuste substratum vir spraakproduksie. ${ }^{20}$ Die reflekssisteme word gekoördineer met die willekeurige meganismes deur die dalende projeksiebane vanaf die serebrale korteks, nl. die kortikobulbêre en kortikospinale bane. ${ }^{21}$ Enkele reflekse kan waarneembaar uitgelok word in die spraakorgane, nl. die faringale, palatale en mandibulêre reflekse. Die reflekssisteme kan beskou word as die meer outomatiese, meer georganiseerde en meer eenvoudige aspekte van orale funksies tydens spraakontwikkeling en gestabiliseerde spraak, en word dus onderskei van die infantiele reflekse wat as mees outomaties geklassifiseer is. Die vegetatiewe funksies, die velofaringale sfinkter, respirasie en fonasie word op grond van hul funksionering op 'n laer bewussynsvlák deur die skryfster gegradeer as meer outomatiese, meer georganiseerde én meer eenvoudige funksies. As 'n derde vlak, word die ontwikkeling van artikulasie en artikulasie tydens gestabiliseerde spraak, as die meer willekeurige, minder georganiseerde en meer komplekse aspek van orale funksionering, onderskei.

Daar kan dus tot die slotsom gekom word dat gestabiliseerde spraak gegradeerde komponente bevat, met ander woorde, outomatiese en willekeurige aspekte. Genoemde gradering dui dus nie slegs die orde van ontwikkeling aan nie, maar gee 'n aanduiding van die neuro-evolusionêre organisasie en funksionering op enige stadium. 
Met die oog op die praktiese toepassing van die teoretiese besinning, is daar as volg te werk gegaan:

1: Daar is 'n hiërargiese spraakskema opgestel wat die neuro-evolusionêre organisasie van spraakfisiologie aandui en wat as basis sal dien vir die opstel van 'n ondersoekprogram en riglyne sal verskaf vir die behandeling van verworwe disartrie.

2. 'n Ondersoekprogram is saamgestel wat die spraakprobleem van die verworwe disartriegeval in sy totaliteit ondersoek en die neuro-evolusionêre en neurofisiologiese simptome uitlig.

\section{BESPREKING VAN DIE HIËRARGIESE SKEMA}

Bekende feite in verband met spraak word hipoteties georden deur die skryfster en weergegee in die hiërargiese skema. Enkele vereistes is gestel aan die skema:

1. In ooreenstemming met neuro-evolusionêre beginsels moet die skema spraakmotoriek voorstel vanaf die mecs eenvoudige tot die meer komplekse, die mees outomatiese tot die meer willekeurige, en vanaf die mees georganiseerde tot die minder georganiseerde vlakke van funksionering.

2. Die subsisteme van spraakfisiologie, nl. respirasie, fonasie, artikulasie, resonansie en vegetatiewe gedrag, word alles in ag geneem en ook die interskakeling moet na vore kom aangesien geeneen van die subsisteme onafhanklik bestaan nie.

3. Die skakeling met sensoriese terugvoering word ook op die skema aangegee aangesien spraak sensories-motoriese gedrag is.

4. Vir praktiese doeleindes moet die skema van waarde wees in die diagnose van motoriese spraakprobleme en ook riglyne verskaf vir die behandeling van die probleme. Die skema word dan ook in vlakke verdeel wat stadia in die ontwikkeling van spraak en organisasie in die gestabiliseerde stadium aandui ten einde die teorie meer konkreet voor te stel. Dit gee noodwendig aanleiding tot ' $n$ mate van oorvereenvoudiging aangesien spraak in sy totaliteit uiters kompleks is en moeilik grafies voorgestel kan word. Die voorstelling van die hiërargiese spraakskema is soos reeds gesê, bloot hipoteties en kan slegs deur verdere uitgebreide navorsing bevestig word. In 'n voorlopige ondersoek gedoen deur die skryfster, is bevind dat dit reeds in die huidige vorm tot 'n groot mate ooreenstem met die orde van devolusie en herevolusie in die verworwe disartriegeval en van groot praktiese waarde is.

Enkele aspekte van die skema word vervolgens bespreek:

\section{RESPIRASIE}

Respirasie is die mees basiese funksie van alle lewende wesens en dit word slegs sekondêr aangepas vir spraakdoeleindes deur geleidelike dieper respirasie met vinnige inspirasie en gekontroleerde verlengde ekspirasie. Die uitvloei van lug word ook gevarieer om verhoogde subglottale druk te verkry wat aangepas word vir die klempatrone van 'n taal. 


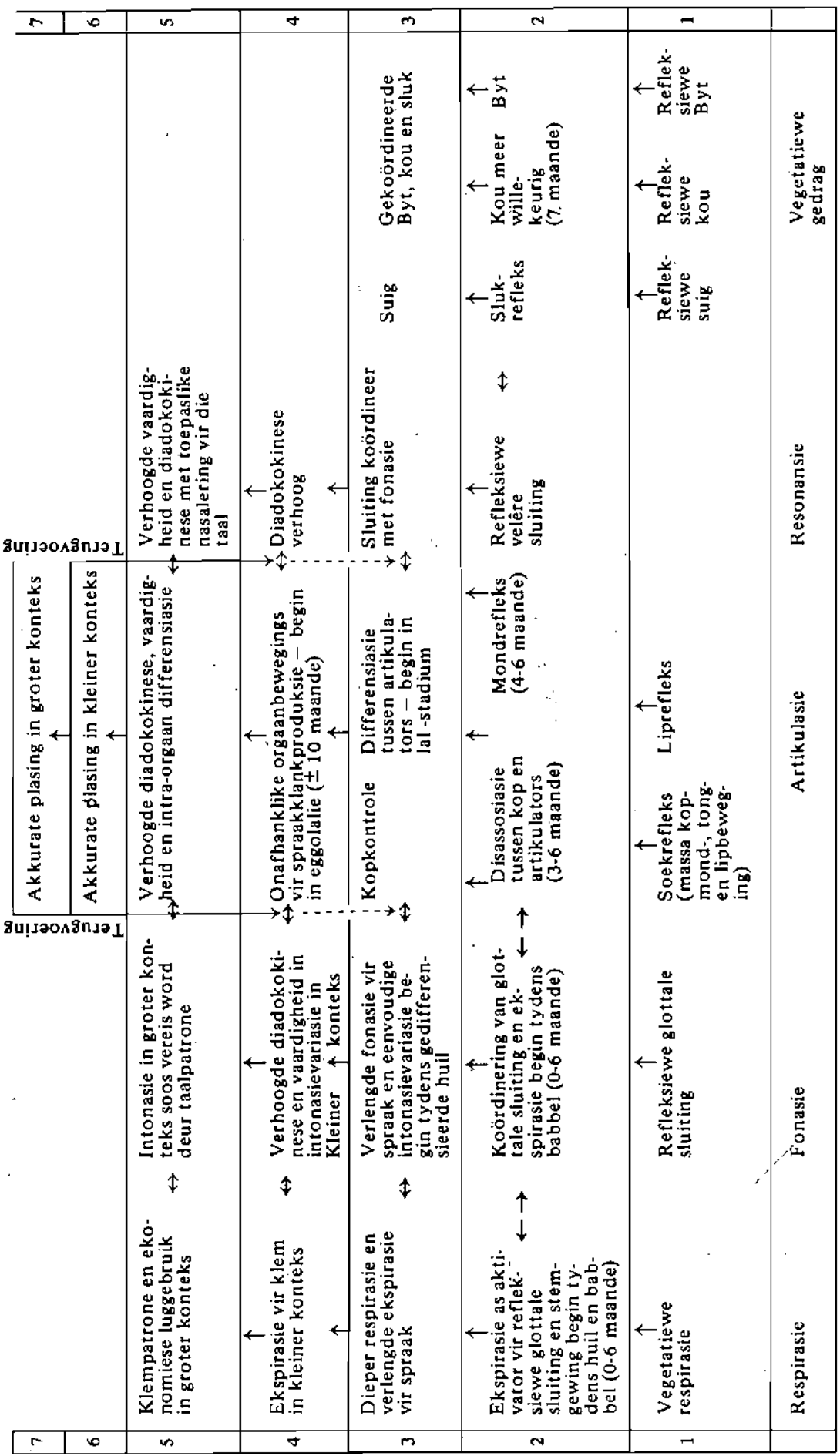

Journal of the South African Speech and Hearing Association, Vol. 23. December 1976 
FONASIE

Glottale adduksie is aanvanklik suiwer refleksief en so ook die aanvanklike skakeling tussen ekspirasie en glottale sluiting tydens huil. Vanweë die versterking deur sensoriese terugvoering, word die skakeling meer willekeurig en word glottale sluiting gebruik vir fonasie. Die vaardigheid waarmee die fonasiemeganisme gebruik word en die diadokokinese van glottale abduksie en adduksie neem geleidelik toe, asook die vermoë om variasie in intonasie te produseer.

Die stippellyne dui op die begin van interskakeling wat op 'n latere stadium meer vasgelē is, soos aangedui deur die vaste lyn.

Klempatrone en intonasievariasie in die breë konteks van spontane kommunikasie in enige taal word beskou as die mees komplekse vlak van in terskakeling tussen fonasie en respirasie. Vanuit 'n bewussynsvlak gesien kan dié aspek nie op dieselfde vlak gestel word as artikulasie nie, want daar is beperkings op die willekeurige beheer van die aspekte vanweë die beperkte hoeveelheid proprioseptiewe inligting vanaf die fonasie- en respirasie-meganisme.

\section{ARTIKULASIE}

Die soekrefleks word gesien as die basis van artikulasiebeweging aangesien massabewegings van al die artikulasie organe en die kop hierin voorkom. Dit is die beginpunt van latere onafhanklike bewegings. Die liprefleks word ook hier geplaas hoewel dit ook by die meer suiwer vegetatiewe reflekse geplaas kan word. Geisoleerde lipronding is egter op latere stadiums waarskynlik meer verwant aan artikulasie as aan die basiese funksies. Vanuit die soekrefleks ontwikkel kopkontrole en onafhanklike spraakorgaanbe wegings. Die mondrefleks wat 'n gekondisioneerde refleks is, ontstaan op 'n latere stadium en kan moontlik ook by die vegetatiewe funksies geplaas word, aangesien mondopening 'n voorvereiste is vir eet. Dit kan egter ook gesien word as die basis vir latere willekeurige mondopening tydens artikulasie.

Terugvoering speel weer eens 'n belangrike rol in die verdere motoriese ontwikkeling en word op die skema aangedui. Vaardigheid en diadokokinese neem geleidelik toe en artikulasie vereis akkurate plasing in steeds groter wordende kontekse namate die kind yorder vanaf woorde na sinne in sy taalontwikkeling.

\section{RESONANSIE}

Die velum dien aanvanklik as deflektor vir voedsel en hieruit kan afgelei word dat daar aanvanklik nie velêre bewegings voorkom nie. Namate die meer vol. wasse slukpatroon aangeneem word, is dit nodig dat 'n velêre sluiting gevorm word. Die beweging ontstaan waarskynlik dan op 'n latere stadium en word om dié rede op vlak 2 aangedui. Die sluiting word geleidelik gekoördineer met fonasie, die vaardigheid en diadokokinese neem toe, en nasalering vind plaas volgens die vereistes van die taal.

\section{VEGETATIEWE GEDR AG}

Die aanvanklike infantiele orale reflekse word aangedui as die beginpunt van vegetatiewe gedrag. Refleksiewe suig is die beginpunt van die volwasse slukrefleks. Die slukrefleks soos byvoorbeeld vir speekselbeheer, word weer beskou as onderliggend aan die slukpatroon tydens eet in die volwasse stadium. Re- 
fleksiewe kou en byt vorm die basis vir latere gekoördineerde byt en kou. Die suigfunksie word ook op vlak 3 aangedui aangesien dit 'n hoë mate van koördinasie vereis tussen verskillende organe soos die velum, lippe en tong en slegs op 'n latere stadium moontlik is.

Vegetatiewe gedrag is die gebruik van die orale organe vir laer funksies wat nie-simbolies is nie. Dit word egter nie streng gesproke gesien as die basis van artikulasie nie. Die neurofisiologiese organisasie is waarskynlik totaal verskillend aangesien die vegetatiewe funksies onafhanklike kortikale verteenwoordiging het en dus nie net ' $n$ laer orde organisasie van spraakbewegings is nie. Om dié rede word vegetatiewe gedrag as 'n onafhanklike subsisteem aangegee wat ook soos die ander subsisteme nou skakel met artikulasie aangesien dit steeds bewegings van dieselfde organe vereis.

\section{VEREISTES GESTEL AAN DIE ONDERSOEKPROGRAM}

1. Afleidings in verband met neuro-evolusionêre en neurofisiologiese aspekte van die probleem moet gemaak kan word met die oog op diagnose, behandeling en verdere navorsing.

2. Die inligting verkry uit die program moet ' $n$ indikasie gee van die algemene toestand en aard van die probleem aangesien die spraakprobleem as deel of simptoom van die totale probleem gesien moet word.

3. Daar word nie gepoog om die probleem te klassifiseer nie, maar wel om die simptome van die toestand soos dit presenteer in elke individuele pasiënt, na te gaan. Die literatuur dui aan dat die huidige klassifikasie van die motoriese sindroomgroepe nie onomwonde bewys en aanvaar word nie, en die neiging om elke persoon se individuele simptome na te gaan, word bespeur. 'n Individuele benadering is aanvaarbaar en noodsaaklik as in ag geneem word dat die lokalisasie en dus ook die effek van 'n letsel verskil van persoon tot persoon. Dit is egter so dat algemene beginsels met betrekking tot fisiologie ooreenstem in alle persone en aan die hand van die beginsels kan alle persone wel ondersoek en behandel word.

4. Elke subsisteem van spraak word nagegaan vanaf die mees eenvoudige tot die meer komplekse funksies ten einde ' $n$ beeld van die totale spraakprobleem te verkry.

5. Die aandeel van organiese bou in die funksionele probleem moet nie geignoreer word nie. Die wyse waarop die probleem organies presenteer; byvoorbeeld in 'n verlamming, word ook aange teken vanweë die belángrike rol in die sprakkprobleem en die diagnostiese waarde daarvan.

6. Ten einde vaste norms daar te stel, word die moontlike vorme wat 'n toestand kan aanneem aangegee, en die ondersoeke dui slegs met 'n kruisie die aard van 'n toestand aan. Die metode is ook tydsbesparend.

7. Die implikasies van die bevindings moet'ook aan die terapeut wat nie oor 'n diepgaande kennis van die neuro-evolựsie beskik nie, riglyne verskaf vir die doelstellings van terapie.

8. Ruimte word egter ook gelaat vir kwalitatiewe beskrywings aangesien elke 
individuele probleem in sy totaliteit nie deur keusemoontlikhede aangedui kan word nie.

9. Die program moet met gemak en vinnig prakties toegepas kan word.

10. Ruimte word gelaat vir die optekening van resultate op 'n latere stadium, byvoorbeeld na 'n periode van terapie aangesien die verloop van die toestand daaruit afgelei kan word, asook die effek van behandeling, medies sowel as terapeuties. Vir navorsingsdoeleindes kan afleidings ook in verband met her-evolusie gemaak word.

\section{DIE ONDERSOEKPROGRAM VIR VERWORWE DISARTRIE}

\section{Algemene fisiese ondersoek}

1. Spiertonus: normaal; parese; paralise; verlaag; verhoog; links; regs; bilateraal.

2. Reflekse: normaal; verhoog; verswak.

3. Abnormale reflekse: afwesig; teenwoordig.

4. Balans: kopkontrole: goed, swak, geen; kan sit; kan staan; kan loop.

5. Onwillekeurige bewegings: afwesig; teenwoordig.

6. Sensasie: normaal; verlies.

7. Kraniaalsenuweeuitvalle: I-XII; geen.

8. Diagnose:

9. Prognose:

Opmerkings: die algemene fisiese ondersoek moet verkieslik deur die geneesheer voltooi word.

\section{Perifere orale ondersoek}

Die lippe en gesig, mandibula, tong en velum word aan die hand van die volgende aspekte ondersoek waar toepaslik.

1. Bou: normaal; gebreke anatomies; atrofie.

2. Spiertonus: normaal; verhoog; verlaag; links; regs; bilateraal.

3. Simmetrie: normaal; asimmetries: trek na links; regs.

4. Refleksiewe beweging: normaal; verhoog; verswak.

5. Willekeurige beweging: normaal; swak; immobiel; feitlik immobiel.

Spraakmotoriek-ondersoek

A. Infantiele orale reflekse.

1. Soekrefleks: teenwoordig; gedeeltelik; afwesig.

2. Hand-mandibulēre refleks: ditto.

3. Liprefleks: ditto.

4. Suigrefleks: ditto.

5. Kourefleks: ditto. 
6. Bytrefleks: ditto.

7. Mondoopmaakrefleks: ditto.

8. Mandibulêre strekrefleks.

B. Behoue reflekse.

1. Slukrefleks: teenwoordig; verswak; verhoog; afwesig; vertraag.

2. Speekselbeheer: ditto.

3. Faringale refleks: ditto.

4. Palatale refleks: ditto.

5. Mandibulêre refleks: ditto.

6. Gaap: ditto.

C. Vegetatiewe funksies.

1. Byt: normaal; verswak; afwesig; geassosieerde bewegings.

2. Kou: ditto.

3. Gesinkroniseerde byt, kou en sluk: ditto.

4. Sluk: ditto.

D. Respirasie.

1. Dominante tipe: abdominaal; torakaal; gemeng.

2. Diepte van respirasie: normaal; vlak.

3. Gebruik tydens rus: ekonomies; onekonomies.

4. Reëlmatigheid: egalig; onwillekeurige bewegings.

5. As aktivator vir refleksiewe glottale sluiting: voldoende; onvoldoende.

6. As aktivator vir fonasie: voldoende; onvoldoende.

7. Duur van lang ekspirasie sonder stem: ... sekondes.

8. Inspirasiespoed vir spraak: normaal; stadig.

9. Gebruik ty dens spraak: ekonomies; onekonomies.

10. Spraakluidheid: normaal; verswak; verhoog.

11. Konstan theid van toonluidheid: normaal; neem geleidelik af; onwillekeurige bewegings.

12. Ekspirasie vir klempatrone in woorde: voldoende; onvoldoende.

13. Ekspirasie vir klem in groter konteks: voldoende; onvoldoende.

E. Fonasie.

1. Glottale sluitrefleks, byvoorbeeld in hoes: teenwoordig; verswak; afwesig.

2. Willekeurige koördinering met ekspirasie: voldoende; onmoontlik.

3. Duur van verlengde fonasie: ... sekondes.

4. Konstantheid van verlengde fonasie: aanhoudend; wissel; neem vinnig af; onwillekeurige bewegings. 
5. Inisiëringspoed van stem: normaal; vertraag; gering vertraag.

6. Diadokokinese van glottale sluiting: $\ldots$ keer in 5 sek., aaneenlopend.

7. Ritme van glottale diadokokinese: ritmies normaal; stadig ritmies; a-ritmies

8. Beweging tydens diadokokinese: afsonderlik; word aaneenlopend.

9. Algemene toonhoogte: normaal; laag; hoog; wissel.

10. Stemkwaliteit: normaal; swak.

11. Toonhoogtevariasie in sinne: normaal; gering; monotoon.

12. Toonhoogtevariasie in groter konteks: normal; gering; monotoon.

F. Resonansie

1. Palatale refleks: teenwoordig; afwesig; verswak; ontoetsbaar weens verhoogde faringale refleks.

2. Koördinering met fonasie: teenwoordig, afwesig.

3. Verlengde sametrekking met fonasie: normaal; vinnige uitputting; afwesig; on willekeurige bewegings.

4. Diadokokinese van velêre sluiting: ... keer in 5 sekondes.

5. Kwaliteit tydens diadokokinese: goed; onvoldoende bewegings; bewegings word aaneenlopend.

6. Nasale resonansie in spraak: normaal; hipernasaal; hiponasaal.

7. Graad van nasaliteit: gering; erg; totaal.

G. Artikulasie.

Spraaksisteemdifferensiasie: goed; gedeeltelik; geen.

1. Kop van toraks.

2. Artikulators van kop en nek.

3. Lippe van kaak en tong.

4. Tong van kaak en lippe.

5. Kaak van tong en lippe.

6. Intra-orgaandifferensiasie.

Diadokokinese: ... keer in 5 sek; ontoetsbaar.

1. Enkelartikulasie.

i) Nie-spraakbewegings: tong in en uit; tong heen en weer; lippe; kaak.

ii) Spraakbewegings: tong; lippe; kaak; velum (bv. la; pa; ka; pm)

2. Twee-plekartikulasie.

i) Voor na agter in mond.

ii) Voor na middel.

iii) Agter na voor.

iv) Agter na middel.

3. Drie-plekartikulasie

i) Voor, middel en agter van mond.

ii) Agter, middel en voor. 
iii) Middel, voor en agter.

Artikulasie

1. Aard van artikulasie: akkuraat; goed; swak; baie swak; uiters swak; weggelaat.

i) Bilabiaal.

ii) Labiodentaal.

iii) Palataal.

iv) Alveolêr.

v) Velêr.

vi) Vokale.

vii) Klankverbindings.

2. Algemene indruk van artikulasie: goeie artikulasie; verswakte artikulasie; uiters verswak; erg verswak; weinig artikulasiebewegings.

3. Gelykvormigheid van artikulasie in spontane spraak: konstant dieself de geartikuleer; varieër; breuke in artikulasie; verswak met uitputting.

Artikulasie tydens diadokokinese:

1. Kontinuiteit van bewegings: bly behoue; neem vinnig af; geleidelik; onwillekeurige bewegings; feitlik immobiel.

2. Ritme tydens diadokokinese toetsing: ritmies; stadig ritmies; a-ritmies.

3. Akkuraatheid van plasing: goed; swak; baie swak.

4. Geassosieerde bewegings van: ander artikulators; ander liggaamsbewegings.

5. Spoed van spontane spraak: normaal; stadig; baie stadig; on reëlmatig.

H. Vlotheid van spraak:

1. Vlotheid van spraak: normaal; onvlot.

2. Ritmespoed van spraak: normaal; stadig; wissel.

I. Kompensasie.

Kompenseer deur: geen; spoed van spraak; addisionele bewegings.

J. Verstaanbaarheid.

1. Verstaanbaarheid van spontane spraak: goed; swak; baie swak.

2. Verstaanbaarheid tydens: woorde; sinne; spontane spraak.

K. Indruk van algemene erns van toestand: uiters swak; baie.swak; swak; ge-

middeld; gering; weinig.

\section{BEHANDELING VAN VERWORWE DISARTRIE}

Nadat die vlak van funksionering van elke subsisteem van spraak bepaal is met behulp van die ondersoekprogram, is die doel van terapie om waar moontlik, 'n herevolusie te bewerkstellig. In 'n degeneratiewe of statiese toestand word ondersteuningsterapie gedoen om devolusie teë te werk. Binne die raamwerk wat die skema bied kan verskeie tegnieke toegepas word ten einde die neurofisiologiese disfunksie, byvoorbeeld 'n parese, te verbeter. Keuse van tegnieke 
word aan die diskresie van die terapeut oorgelaat ten einde aan te pas by die behoeftes van die pasiënt.

Die metode wat gevolg moet word kom neer op:

1. Inhibisie van positiewe simptome indien dit voorkom.

2. Fasilitasie van negatiewe simptome. Die metode word hoofsaaklik gevolg in spraakterapie aangesien spraak as 'n hoër funksie hoofsaaklik uit negatiewe simptome bestaan.

Tegnieke wat gebruik kan word, is die volgende:

1. Mysak ${ }^{11,12,13}$, beskryf tegnieke wat veral waardevol op die refleksvlakke gebruik kan word.

2. Proprioseptiewe neuromuskulêre fasilitasietegnieke wat gerig is op die verbetering van onderliggende bewegingspatrone, is uiters geslaagd. Die tegnieke is veral van waarde by fasilitering van die middelvlakke, byvoorbeeld verlengde ekspirasie en onafhanklike orgaanbewegings.

3. Willekeurige pogings, byvoorbeeld by diadokokinese verbetering.

4. Tradisionele spraakterapeutiese grondbeginsels, byvoorbeeld multisensoriese stimulasie en motivering van pasiënt.

Hippocrates het gesê dat genesing nie slegs afhanklik is van tyd nie, maar ook van geleentheid, en dit is die verantwoordelikheid van die spraakterapeut om aan elke pasiënt wat in haar sorg geplaas word, die maksimum geleentheid tot herstel te bied.

\section{VERWYSINGS}

1. Bobath, K. (1969): The motor deficit in patients with cerebral palsy. Clinics in developmental medicine No. 23. William Heineman Medical Books.

2. Brain, R. (1956): Diseases of the nervous system. University Press, London.

3. Crickmay, M.C. (1972): Speech therapy and the Bobath approach to cerebral palsy. Charles $\mathrm{C}$. Thomas, lllinois.

4. Crouch, Z.B. (1971): Lip taping for buccal-labial insufficiency. $J$. Speech Hear. Dis., 36, 543-545.

5. Darley, F.L., Aronson, A.E. \& Brown, J.R. (1969): Differential diagnostic patterns in dysarthria. J. Speech Hear. Res., 12, 246-270.

6. Darley, F.L., Aronson, A.E. \& Brown, J.R. (1969): Clusters of deviant speech dimensions in the dysarthrias. J. Speech Hear. Res., 12, 462-297.

7. Hixon, T.J. \& Hardy, J.C. (1964): Restricted motility of the speech articulators in cerebral palsy. J. Speech Hear. Dis., 29, 293-306.

8. Ingram, T.T.S. (1973): Developmental disorders of speech. Handbook of Clinical Neurology, Vol. 4, Disorders of speech, perception and symbolic behaviour. American Elsevier Publishing Co., New York.

9. Jackson, J.H. (1925): Neurological fragments. Oxford Medical Publications. 
10. Morley, D.E. (1955): The rehabilitation of adults with dysarthric speech. J. Speech Hear. Dis., 20, 58-64.

11. Mysak, E.D. (1959): Significance of neuro-physiological orientation to cerebral palsy habilitation. J. Speech Hear. Dis., 24, 221-230.

12. Mysak, E.D. (1963): Dysarthria and oropharyngeal reflexology: a review. J. Speech Hear. Dis., 28, 252-260.

13. Mysak, E.D. (1968): Neuro-evolutional approach to cerebral palsy and speech. Teachers College Press, New York.

14. Peacher, W.C. (1950): The etiology and differential diagnosis of dysarthria. J. Speech Hear. Dis., 15, 252-265.

15. Tikofsky, R.S. \& Tikofsky, R.P. (1964): Intelligibility measures of dysarthric speech. J. Speech Hear. Res., 7, 325-333.

16. Wedin, S. (1972): Rehabilitation of speech in cases of palato-pharyngeal paresis with the aid of an obturator prosthesis. British J. Dis., Comm., 7, 117-129.

17. Weiss, D.A. \& Beebe, H.H. (1951): The chewing approach in speech and voice therapy. S. Karger, New York.

18. West, R.W., Ansberry, M. \& Carr, C. (1957): The rehabilitation of speech. Harper \& Brothers, New York.

19. Wolski, W. (1967): Hypernasality as the presenting symptom of Myasthenia Gravis. J. Speech Hear. Dis., 32, 36-38.

20. Wyke, B. (1966): Recent advances in the neurology of phonation: phonatory reflex mechanisms in the larynx. Speech pathology diagnosis: Theory and practice, Report of the National Conference of the College of Speech Therapists in Glasgow. E. \& S. Livingstone, London.

21. Wyke, B. (1970): Neurological mechanisms in stammering: an hypothesis. British J. Dis., Comm., 5, 6-15. 


\section{tonal purity}

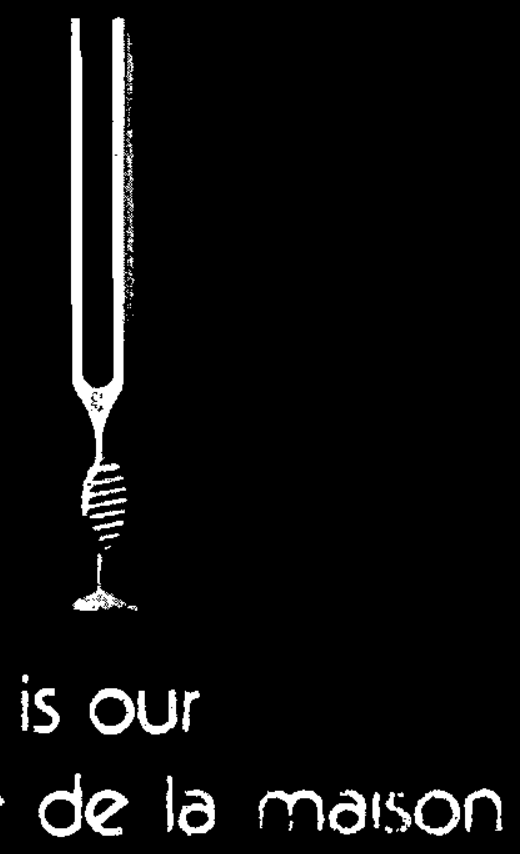

. And it has been since 1948, when we began. They tell us that today's state-of-the-art of audioelectronics owes much to Studer research and specialisation in this field.

. We're human. So we blush.

But we must agree that we design and manufacture audio equipment of superb quality. - In a product

STUDER - REVOX - AKG - THORENS Professional Recording and Audio Mixing Equipment lor Radio. Television, Motion-Picture and Disc-Recording Studios range unequalled in its bracket ... Which is the highest.

We supply this equipment to professionals and discerning amateurs throughout the world. - They buy it for its tonal purity.

.. And that, as we said, is the speciality of our House.

STUDER-REVOX SOUTH AFRICA (PTY)LTD Microphones. Amplifiers, Turntables. FM-Tuners, Loudspeaker Systems, Language Laboratory Installations, Audio-

Visual Teaching Equipment

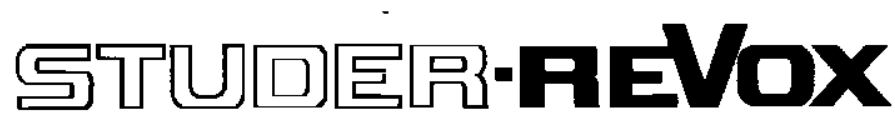

STUdeR-REvoX SOUTH AFRICA (Pty) Ltd., Audward House, 30 Ameshoff Street, Braamfontein. 2001. Tel, 724-9580/88 P.O. Box 31282, Braamfontein. 2017. Telex B-6683 